ARTICLE

Received 26 Feb 2017 | Accepted 12 Jul 2017 | Published 16 Aug 2017

DOl: $10.1057 /$ palcomms.2017.82

OPEN

\title{
"Beauty in the lap of horror": the Gothic appeal of Erich von Stroheim in Blind Husbands (1919) and Foolish Wives (1922)
}

\author{
Elisabetta Girelli ${ }^{1}$
}

\begin{abstract}
This article revisits a seminal figure of film history, the director/actor/scriptwriter Erich von Stroheim, focusing on his early work, and arguing that a Gothic framework is the most appropriate context for making sense of his complex, subversive persona; equally, the essay shows how two films dealing with urban, sophisticated characters, set in modern locations such as Monte Carlo, are in fact drenched in Gothic sensibility and aesthetics. As the director and star of Blind Husbands (1919) and Foolish Wives (1922), the Austrian-born Erich von Stroheim has so far been analysed as a catalyst for post-WWI stereotypes of unwelcome foreignness in the USA. Irrupting in a context fraught with anxieties about "evil Huns", immigration, and ambivalent notions of Europeanness, Stroheim's films caused both outrage and admiration. While film scholars have read Stroheim's perceived transgression through his symbolic role of Germanic alien, they have paid scant attention to the films themselves. This omission has effectively ignored other powerful evocations emerging from Stroheim's work, and the way its suggestions of contemporary identities are subsumed into a much wider, richer narrative: a Gothic narrative. Equally, scholars have correctly mobilized, yet not fully addressed, the essential contradiction at the basis of Stroheim's roles: their inexplicable quality of repulsion-attraction, or in other words, Gothic abjection. This article acknowledges the films' linkability to post-WWI xenophobia, yet argues that their subversive aspects lie in a Gothic system of signification, allowing for yet vastly exceeding cultural and national references of the period; the Gothic also provides a framework where the unresolved tensions of Stroheim's work can meaningfully coexist. Blind Husbands and Foolish Wives centre on a staple Gothic figure, the aberrant male seducer, a "satanic" protagonist who is both molester and object of erotic desire, irresistible yet repulsive. Visually and narratively reliant on Gothic tropes, from "sublimely horrible" mise-en-scene to intimations of rape and sadism, the films daringly validate not the merely objectionable, but the abject, embodied in Erich von Stroheim's perverse masculinity.
\end{abstract}

\footnotetext{
${ }^{1}$ University of St Andrews, St Andrews, UK Correspondence: (e-mail: eg51@st-andrews.ac.uk)
} 


\section{Introduction}

$\mathrm{n}$ the semi-darkness of a stormy evening, swathed in torrential rain, a man and a woman are by the shore of a lake. Sky and ground are blurred into a grey mass of water. A wooden bridge crashes, hit by lightning, as thundering bolts rage overhead. The man urges the woman towards a small boat, but she resists, looking frightened; she then falls, tripping in the drenched vegetation, and appears close to fainting. The man lifts her up, holding her in his arms as he reaches the boat. He is short and thin, almost elf-like, and moves quickly in the violent rain; after placing the woman inside the vessel, he starts paddling outwards. The boat soon starts to be flooded, yet the man keeps going, showing no hesitation or fear; his companion lies motionless, her body half-covered by the rising water. The man steps off the boat into the lake, and is submerged almost to the waist; without faltering, he again takes the woman in his arms, and makes for the other shore in the unceasing deluge.

Contrary to what they may suggest, these images are not taken from an English novel of the Romantic period; they belong to a scene in Foolish Wives (Erich von Stroheim, 1922), a film set in modern, glamorous Monte Carlo in the roaring 20s. Foolish Wives was Stroheim's third film as a director, following Blind Husbands (1919) and The Devil's Passkey (1920). While all three films are set in Europe, Blind Husbands and Foolish Wives are linked in crucial ways: exclusively based on Stroheim's own stories and scenarios, they star Stroheim himself as the male protagonist, and both plots deal with married American women falling for caddish European men. In many ways, Foolish Wives feels like a deeper, more polished treatment of themes already present in Blind Husbands. The two films also bookend a shift in the reception of Stroheim's work. Blind Husbands was hailed as the debut of a genius, of a worthy heir to D.W. Griffith, and if its quasi-adulterous narrative was gasped at, it was still accepted as being "cleanly handled". Foolish Wives, while maintaining Stroheim's reputation as a master filmmaker, provoked savage attacks from the press, who denounced it as an obscenity and an insult to the American public. Both films were box office hits; yet Stroheim's image as "the man you love to hate", playfully used to advertize Blind Husbands, crystallized into an indictment of degenerate immorality with Foolish Wives. Released in the aftermath of WWI, the films are further linked by their placement in an American cultural landscape where notions of "evil Huns" (notions commonly associated with Stroheim at the time) had acquired an almost mythical quality.

The films' exceptional impact on their contemporaries has been ably discussed by Staiger (1992) and Fischer (1994); while compelling and exhaustive in mapping out cultural contexts, however, these authors have paid scant attention to the films themselves. The apocalyptic storm of Foolish Wives, and its relation to the man who exploits it to subdue a woman, have been ignored. Similarly, in Blind Husbands, the American wife's inexplicable dread of the man she finds attractive, and the man's link to mountain landscapes of sublime horror, have received no notice. This essay aims to expand on existing scholarship on the films, while entering in a dialogue with it and challenging some of its assumptions. Specifically, it proposes the Gothic realm as an aesthetic and semantic key to Blind Husbands and Foolish Wives, and to Erich von Stroheim's presence in them; it argues that the films' transgression lies in a system of signification which includes, yet vastly exceeds cultural and national references of the period. In so doing, this essay hopes to expand current notions of "the Gothic" to reveal its presence in a cultural configuration not usually associated with it: Hollywood marital melodrama of the silent period. The intense Gothic sensibility of Stroheim's films offers a new reference for the conventions and tropes linked to Gothicness, locating them in the unlikely scenario of tourist erotic escapades and the glamorous 1920s; equally, the perversion of orthodox masculinity, achieved through Stroheim's uniquely bizarre persona, shows a different brand of "satanic" male, asking us to rethink the boundaries of gendered and visual Gothicness.

Set in contemporary times, yet devoid of direct allusions to WWI and its aftermath, Blind Husbands unfolds its narrative in a forbidding Alpine landscape. The dangerous importance of the mountains is immediately made clear: the first credits roll over an image of snow-capped peaks, followed by a dedication to "Sepp Innerkofler, world-famous mountain guide", whose "pure and mighty heart" led him to rescue those in danger, leading to his "sacrifice" on the Monte Cristallo. This information is followed by two more intertitles. The first is a disquisition on divorce: considering how often "the other man" is seen as the guilty party in a marriage breakdown, it points out that the latter steps in when a woman is neglected by her husband, who is, therefore, himself not without guilt. The second title is intercut with a view of a steep mountain summit: it announces the film's locations, the Monte Cristallo "as old as the world itself", and the village of Cortina, described as being "almost choked by the nearness of this Alpine magnitude". These preambles spell out and link together some of the film's main issues: the ambiguity of human nature, connected with both "purity" and "guilt", and the atavistic force of the mountains, which may kill or "choke" who goes near them. The film then starts by showing Cortina on a Sunday, with the faithful coming out of a church; among them is the guide Sepp (Gibson Gowland), a big and rustic-looking man, who soon enters the local restaurant and is handed a telegram. He learns from it that Dr Armstrong and his wife, American tourists, are about to arrive in Cortina. Through a brief flashback, he remembers how the previous year he saved Dr Armstrong's life, bringing him to safety during a dangerous climb; Armstrong (Sam De Grasse) is recalled calmly waiting to be rescued, and then composedly shaking Sepp's hand. Back in the present, the main characters are introduced, shown travelling by carriage to their hotel: Armstrong and his wife Margaret (Francelia Billington), and the Austrian Lieutenant Erich von Steuben (Erich von Stroheim). Margaret appears completely ignored by her husband, who is absorbed in reading, and who does not even answer her when she asks him the time; Von Steuben promptly replies in his place, with solicitous chivalry. So far, the camera has only provided a brief glimpse of the Lieutenant, nattily dressed in a skin-tight uniform with matching gloves; more time has been given to close-ups of Margaret, whose lovely face is tinged with sadness, and of Dr Armstrong, bespectacled and undistinguished. The carriage's arrival in Cortina, however, affords a full view of the Austrian officer. A medium-close up shows him flanked by two local men: Von Steuben, much smaller than them, nonetheless dominates the frame through his striking appearance and central position. A half-pan over his body reveals his waif-like size and narrow shoulders, while his tall military hat and stiff high collar squeeze his face into prominence. It is a gaunt yet curiously fleshy face, set to an arrogant, even hostile expression; the hat covering Von Steuben's forehead emphasizes his bulky nose and ears, which seem abnormally large in relation to his body. A twist in his mouth suggests cruelty. Overall, Von Steuben looks unkind and slightly monstrous, a sort of malevolent gnome; he communicates a uniquely menacing power. Equally, his peculiar appearance, elegant yet imperious manners, and resplendent military clothes are at odds with everyone else on screen.

The film cuts to the next morning, and to the hotel guests going to breakfast. Margaret tells her husband she has forgotten her sweater in their bedroom, but Dr Armstrong makes no effort to retrieve it; Von Steuben, who has overheard them, sneaks into 
the room and gets the sweater for Margaret. From this moment, the plot charts the growing intimacy between the Austrian officer and the American woman, interweaving this major thread with two other key narrative strands: Margaret's suffering from her husband's neglect, and Von Steuben's irresistible power of attraction to women. The only female immune from his erotic allure is a honeymooning wife (Valerie Germonprez, Stroheim's wife-to-be in real life), whose happiness in the company of her husband (Jack Perrin) makes for a painful comparison with Margaret's situation. As Von Steuben's pursuit of his American prey gets more daring (he fondles Margaret's breast and tries to kiss her during a walk in a cemetery, provoking her half-hearted resistance), Dr Armstrong leaves the hotel, to join a mountain rescue party for some stranded American tourists. That night Von Steuben finds his way to Margaret's bedroom, where his sexual advances are met with a dramatic mixture of thrill and terror. "I promise-but give me time!" she pleads, wildly affected (Fig. 1). He leaves her, and later Margaret has a nightmare in which Von Steuben's face looms hugely, like a disembodied object of horror. Next, the Lieutenant joins the Armstrongs and other guests on a climb, when they see a road sign that visibly unsettles them: it marks the place where a jealous husband pushed his wife's seducer off the mountain, many years before. As the group stops at a refuge for the night, the Armstrongs take up separate rooms, to avoid Margaret being disturbed by the Doctor's early departure for the Pinnacle, the mountain's highest point. Von Steuben reminds Margaret of her promise; when he later reaches her room, however, he finds that the vigilant Sepp is occupying it in her place. The next day, Von Steuben and Armstrong reach the Pinnacle. There the American gets hold of his rival and holds him at the cliffs edge, threatening to push him off if he doesn't tell the truth: did Margaret promise to run away with him? Von Steuben, petrified, replies that she did. Armstrong does not kill him, yet cuts the rope that joins them and abandons him there. Meanwhile, Margaret is having inexplicable forebodings about the two climbers, and begs Sepp to go and rescue them; he sets off with an Austrian army patrol. All the while Von Steuben, alone on the peak, is being overcome by fear and horror. Birds of prey circle around him. Dr Armstrong, who has fallen and broken an arm, is rescued by Sepp, and later sees a piece of paper floating in the air: it is a note from Margaret to Von Steuben, fallen out of the latter's pocket, proclaiming her faithfulness to her husband. Mollified, Armstrong tells the rescue team to go and get the Lieutenant. But it is too late. Seized by unspeakable terror, pacing the mountain's edge to and fro like a madman, Von Steuben loses his balance and plunges down to his death. The film ends with the Armstrongs' sober departure from Cortina.

Defined by an oddly repulsive appearance and alien characterization, a devastating power over the opposite sex which blends eroticism with terror, and a personal, horrific connection to the forces of nature, Von Steuben dominates Blind Husbands, not least because of Stroheim's superb performance. In Foolish Wives, the Stroheim character retains Von Steuben's key traits, but these are developed to construct a truly diabolic figure; equally, the film's disturbing elements greatly exceed the unsettling aspects of Blind Husbands.

Foolish Wives starts by introducing its location, Monte Carlo, with the image of a spinning roulette, while describing the place as "Europe's playground-irresponsible and gay as ever when the Armistice was signed". After an aerial shot of this glamorous principality, the film shows a view of the nearby Villa Amorosa, a walled mansion on the lonely top of a rocky cliff, with the sea straight below. The Villa has been rented to "three Russian aristocrats", who soon appear: first the ladies, Princesses Olga and Vera Petchnikoff (Maude George and Mae Busch), seen walking towards a balcony overlooking the sea. The other female presence

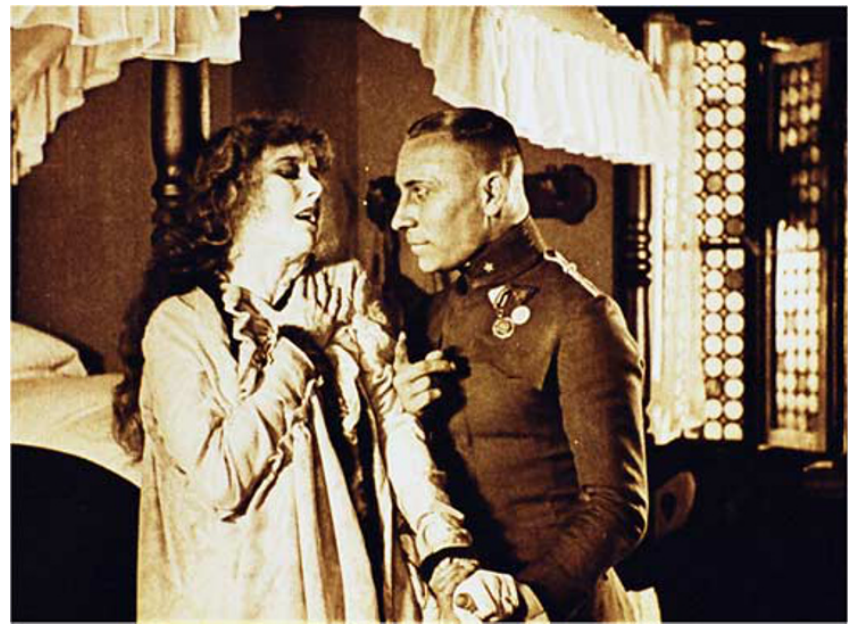

Figure 1 | Margaret is thrilled yet terrified. From Blind Husbands (Erich von Stroheim, 1919). This figure is not covered by the Creative Commons Attribution 4.0 International License. Reproduced with permission of the copyright holder, Austrian Film Museum/Frame enlargement Georg Wasner.

is the maid Maruschka (Dale Fuller), a demure-looking woman with a sad expression. As the camera moves to the seashore, the Princesses' cousin is introduced: he is Captain Count Vladislaw Sergius Karamzin (Erich von Stroheim), standing on the rocks in an elegant dressing gown, holding a gun in his hand and apparently shooting in the water. Once the camera gets nearer, Karamzin points the gun straight at it, and thus at the audience; with the severest of military haircuts, his face cast in a deep frown, and his eyes squinting coldly, he appears unsympathetic. The real aim of his gun now comes into view: a target with the face of a man, bearing the marks of the Count's excellent shots. Summoned to breakfast, Karamzin ascends the stairs to the balcony, and here he is fussed and waited upon by all the women. He immediately drinks a glass of oxblood, defined as his usual "eye-opener" by a title card. The cousins' repast is interrupted by the arrival of counterfeiter Cesare Ventucci (Cesare Gravina), who is there to provide the Russians with fake banknotes; he is accompanied by his daughter Marietta (Malvina Polo), a mentally disabled girl carrying a doll, and looking exceedingly fazed (Fig. 2). While Ventucci goes away with Princess Olga to conduct their financial business, Marietta is left alone with Karamzin. He surveys the girl's body, then smacks his lips, looking furtively around to make sure no-one is there. His erotic interest in the vulnerable girl-child is obvious; he has just got closer to her, however, when the others come back. Karamzin then strokes Marietta's hair, a gesture unequivocally sinister by now.

The film moves on to its American characters, the diplomatic envoy Mr Hughes and his pretty wife (Rudolph Christians and Miss DuPont), who are just arriving in Monte Carlo. Their presence is announced in the local press, and the Russian cousins are shown commenting on it; they decide that Karamzin will meet and woo Mrs Hughes, for the sake of "business".

Mr Hughes is then shown going to the Royal Palace, while his wife settles in the hotel's terrace with a book; she soon finds a man sitting opposite her, none other than Karamzin in his finest military attire. Like Von Steuben in Blind Husbands, the Count wears a skin-tight uniform, complete with the trendiest accessories; he looks small and vaguely reptilian. Obsequious towards Mrs Hughes, yet looking at her legs so blatantly that she instinctively pulls her skirt down, the Count manages to be formally introduced to her. While slightly alarmed by the Russian's audacious stare, Mrs Hughes is visibly flattered by his 


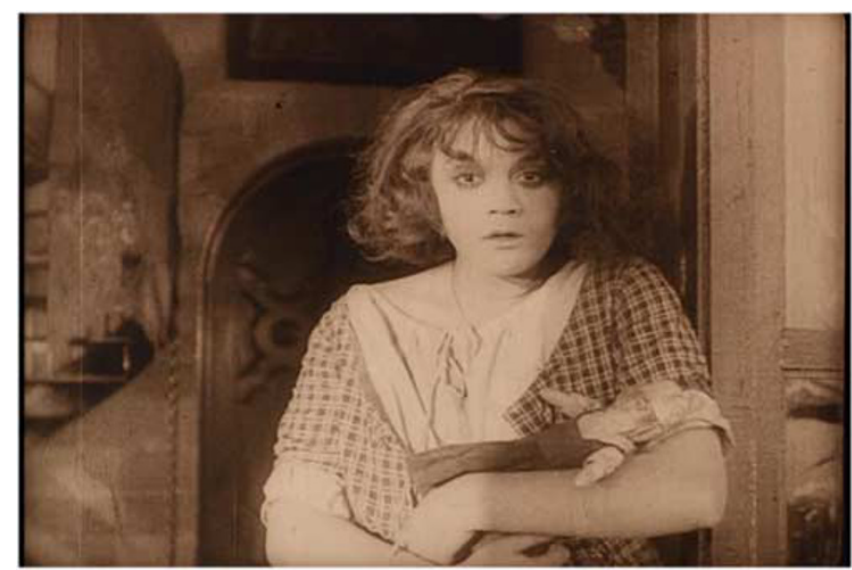

Figure 2 | Marietta looks child-like and vulnerable. From Foolish Wives (Erich von Stroheim, 1922). This figure is not covered by the Creative Commons Attribution 4.0 International License. Reproduced with permission of the copyright holder, Kino Lorber, Inc.

attention, and rapidly attracted by his suave persona. Next, the Count takes the Americans out for the evening, to a cruel bird-shooting event; the wife's initial distress at the spectacle turns to thrilled fascination with Karamzin's shooting prowess. At the following social occasion, Mrs Hughes is clearly excited by the Count's sexually insinuating presence, and tells him that her husband neglects her. Karamzin presses on with his chase: at the first opportunity he suggests that he and Mrs Hughes "go for a walk". She accepts, and once she starts following the Russian through unfamiliar paths, the weather changes and a terrific storm breaks out. Led by the Count to a solitary lake, under a torrential downpour, Mrs Hughes falls and hurts her foot; frightened and faint, she is carried to the other shore by Karamzin, who takes her to a house belonging to Mother Garoupe (Louise Emmons), a witch-like old woman. In close proximity to a goat and other animals, Karamzin puts Mrs Hughes to bed: she reacts with fear when he touches her leg, but quickly succumbs to exhaustion. After Garoupe has also fallen asleep, the Count removes his belt and, continuing to loosen his clothes, advances towards the slumbering Mrs Hughes. Just at this point, however, a monk lost in the storm (Nigel De Brulier) arrives at the door, thus ruining Karamzin's schemes. The latter spends the night near the goat.

The next morning the weather has cleared, allowing everyone to go home; while Mrs Hughes finds her husband unconcerned by her escapade, Karamzin is involved in a scene with Maruschka, who is distressed and tearful. It transpires that the Count had previously seduced the maid and promised to marry her; he now attempts to reassure her and gives her a kiss, wiping his mouth afterwards. He then goes to Ventucci's house, where young Marietta lies ill and bedridden, sleeping in a darkened room. While her father is preparing the fake money, Karamzin furtively approaches the girl, again smacking his lips; he exudes a menacing lust. But just as he bends over the sleeper, he hears Ventucci returning, and rapidly moves away. Back at the Villa Amorosa, more passionate drama from Maruschka awaits him: this time the Count invents a sad story about his financial troubles, and persuades the infatuated woman to give him all her life savings. The action moves again to Monte Carlo society, and Karamzin watches Mrs Hughes win a huge sum at the roulette. She declines Princess Olga's invitation to join them at home for more gambling, but then receives a note from the Count, begging for a secret meeting at the Villa. Unable to resist, Mrs Hughes goes to Karamzin and is seen by Maruschka, who is driven insane

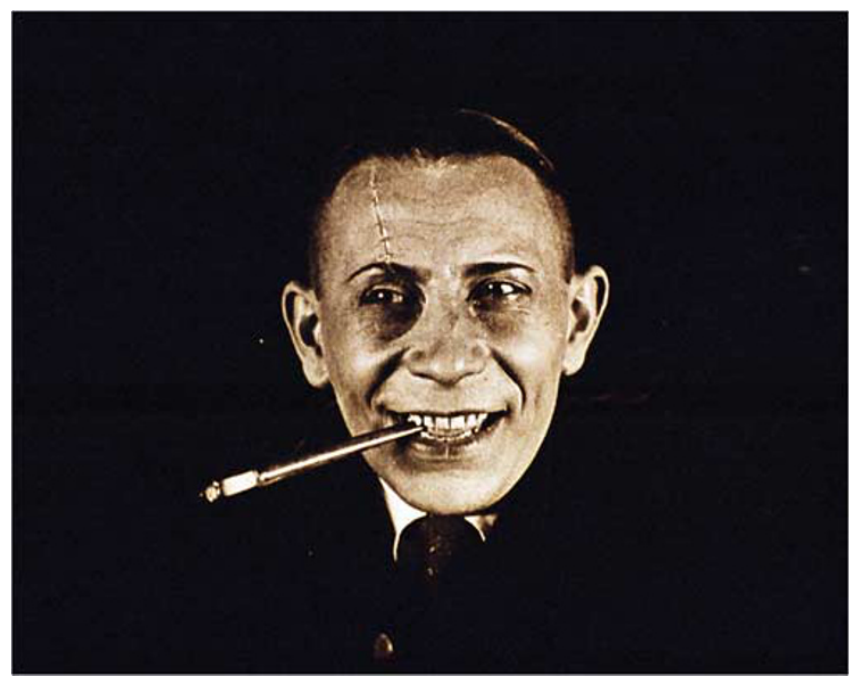

Figure 3 | Wicked: the man they loved to hate. From Blind Husbands (Erich von Stroheim, 1919). This figure is not covered by the Creative Commons Attribution 4.0 International License. Reproduced with permission of the copyright holder, Austrian Film Museum / Frame enlargement Georg Wasner.

by jealousy. In a hysterical frenzy, the maid locks Karamzin and Mrs Hughes in a room on the top floor; she then sets fire to the room. The Count has barely induced the American to "lend" him her roulette winnings, when they notice the smoke and fire; trapped by the locked door, they run to the balcony, as huge lapping flames get nearer and nearer. It is a devastating fire, and the frame is entirely filled by it at times. The fire brigade arrive at last, holding a safety net for the couple to jump to: but Mrs Hughes, paralysed by terror, cannot bring herself to do it. The Count leaps down to his rescue, leaving the lady to her fate; she finally makes it and is taken to her hotel. Meantime, the distraught Maruschka has walked to the cliff top, from where she jumps to her death. More horror is to come, as Karamzin now goes to Ventucci's house and climbs up to Marietta's bedroom: she sees him, and he motions to her to be quiet. Once inside, he ominously closes the window shutters. A cut to the Villa Amorosa shows the police arresting the Princesses, who are exposed as faked aristocrats. When the film returns to Ventucci's home, the counterfeiter has killed Karamzin to avenge his implied abuse of Marietta, and is now disposing of his body by throwing it in a sewer. The end shows Mrs Hughes in bed, recovering from her ordeal under her husband's tolerant eye.

Rich with deeply unsettling events and characters, strikingly evocative mise-en-scene, and permeated by sexual and spatial anxiety, Foolish Wives and Blind Husbands have nonetheless been hastily addressed. Despite their layered diegetic structure and dazzling aesthetics, the films have been chiefly valued as sites of cultural clash. Janet Staiger and Lucy Fischer have focused on the links between the films' reception, Stroheim's persona, and the complex discursive web underlying contemporary American society. Specifically, Staiger approaches Foolish Wives as a catalyst for post-WWI crises of national and gender identity; outlining the public outrage that greeted the film's release, she links it to fears of foreigners, of unbridled female desire, and of emasculation. Fischer usefully expands on Staiger's work, considering both films in the light of American notions of German brutality, the rise of the "new woman", and conflictive attitudes towards Europeans. Staiger's and Fischer's analyses form a joint meta-text, whose core idea is that Stroheim's roles relate to xenophobic constructions of non-American manhood. At a time of growing anxiety about 


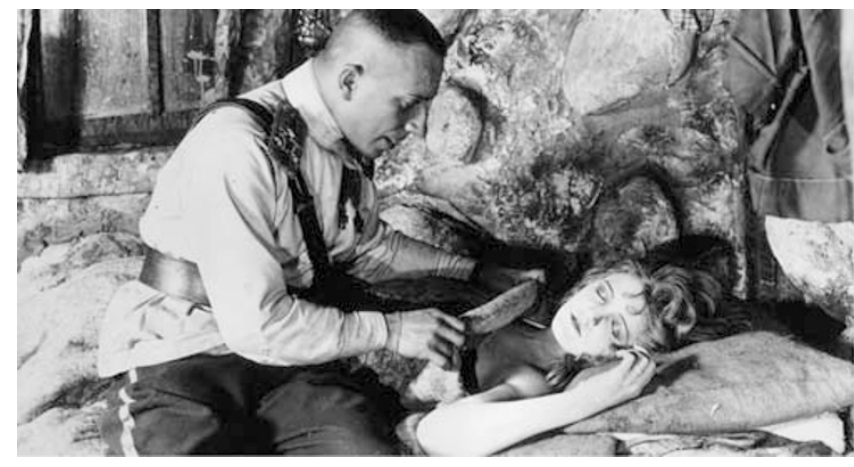

Figure 4 | Beauty in the lap of horror. From Foolish Wives (Erich von Stroheim, 1922). This figure is not covered by the Creative Commons Attribution 4.0 International License. Reproduced with permission of the copyright holder, Kino Lorber, Inc.

"undesirable" immigrants, and with WWI still a recent trauma, the Austrian Von Steuben and the Russian Karamzin are merged with the "man you love to hate" image of Erich von Stroheim (an Austrian Jew by birth), as symbols of menacing, alien masculinity (Fig. 3). Staiger astutely observes that while another screen foreigner, Rudolph Valentino, was also feared as a non-normative seducer of American women, he remained "a desired Mediterranean"; the unpleasantly deviant Stroheim, a Germanic European, functioned as an "undesired Anglo-Saxon" (Staiger's emphasis), just when President Roosevelt was warning of an Anglo-Saxon "race suicide" (Staiger, 137). Even more specifically, Fischer argues that as anti-German feelings were especially high, notions of the "Evil Hun", and their strong association with rape, are readily invoked by Stroheim's characters (Fischer, 525). Stroheim's own cinematic past only reinforced these notions, as his role in The Hearts of Humanity (Allen Holubar, 1918) had seen him as a German soldier who prepares to rape a woman by throwing her baby out of a window.

These considerations provide an essential framework for Blind Husbands and Foolish Wives, and for Stroheim's presence in them: they firmly locate them in their historical context. What they do not do, however, is to explore the films' other powerful evocations, and the way suggestions of contemporary stereotypes are subsumed into a wider, richer narrative. Equally, Staiger and Fischer correctly mobilize, yet do not fully address, the essential contradiction at the basis of Stroheim's roles: their inexplicable quality of repulsion-attraction. Here national stereotypes do not help: the Evil Hun could not conceivably be an object of female desire, he could only violate, never seduce. The sophisticated European may possibly be decadent, not animalistically brutal. Yet Karamzin, and to a milder degree Von Steuben, combine these seemingly antithetical aspects; Staiger and Fischer deal with this primary dualism in two ways. They first relate it to American women's socially transgressive, conflictive, and ultimately opaque desire for a male Other. "Just what did women want?" ponders Staiger, likening Stroheim to Valentino as a source of "desire and scandal" (Staiger 132-137). Fischer describes the films' female protagonists as "credulous women fascinated and repulsed by the European male's nobility and intriguing savoir faire" (Fischer 529).

This clearly will not do: nobility and savoir faire are hardly triggers of repulsion, and to rationalize Stroheim's demonic allure by placing the emphasis on the women fails to explain the diegetic meaning ascribable to him. Staiger's and Fischer's other approach is to displace Stroheim's horror-inducing power onto the hyperbolic reception of it, effectively conflating sign and reaction: in other words, their premise-that the reaction is produced by xenophobia-leads to the implication that the subject being reacted to, Stroheim on screen, must also be read as a xenophobic rendition of available national stereotypes.

While fully acknowledging the films' linkability to their period's clichés and anxieties, this essay seeks a wider, organic signifying system where the unresolved tensions of Stroheim's work can meaningfully coexist. Rather than positing direct identifications between screen images and contemporary tropes, or between sign and reception, it is more useful to start with a close focus on the films themselves, to isolate their primary locus of meaning. This means first of all to separate Stroheim and his roles from the hostility they certainly experienced, and to recover a fundamental aspect of these films, lost through monolithic contextual readings. When, as Staiger reports, contemporary critics decried Karamzin as "an unbelievably contemptible animal" and "monster" (Staiger 132), they were not only venting their likely hatred of "evil Huns" and "degenerate Europeans", as Fischer suggests; they were also describing something deeply present in the film. Karamzin is indeed constructed as an animalistic monster, he is degenerate, he is repulsive, and to a milder extent so is Von Steuben; inexplicably, they both cast a powerful erotic spell on the women they meet, American and European alike. Yet Blind Husbands and Foolish Wives are not especially concerned with the women, despite Fischer's insistence to the contrary. Female narratives are almost inconsequential in the films' structure of feeling, whether part of the main plot of marital crisis, temptation by foreign cad, and return to husband, or in side plots of paedophiliac threat such as Marietta's, or of seduction and abandonment such as Maruschka's. In each case, the women's chief function is to highlight the power of their tempter and abuser, and thus the male protagonist: Stroheim's repulsive character. By presenting Von Steuben and Karamzin as objects of female desire, and by allowing them to carry the narrative through the unique strength and interest of their presence, the films validate and celebrate not the merely objectionable, but the abject. Stroheim's abjection, however, is not reducible to contemporary ideas of Teutonic brutality or effete Europeans: in his untenable and uncomfortable combination of molester and seducer, in his unexplained power of attraction over women, Stroheim harks back to Gothic conventions of previous centuries. The sinister quality of his menace and lure, his disturbing appearance, and his special connection to unsettling locations and mise-en-scene, place him close to monstrously supernatural figures such as Dracula, or to the human yet "satanic" males of staple Gothic fiction. Holding together his roles' conflicting aspects and the very fabric of events in the plots, Stroheim's Gothicness is the structuring key to Blind Husbands and Foolish Wives.

The "Gothic" is a cultural and artistic configuration of potentially huge scope, simultaneously denoting a literary tradition, a set of aesthetic conventions, and a mode of feeling and viewing the world. Rooted in the Romantic and preRomantic periods of English-language novels, and typified by works such as Horace Walpole's The Castle of Otranto (1764) and Ann Radcliffe's The Mysteries of Udolpho (1794), early Gothic also drew upon Edmund Burke's notion of the "sublime", an ideal experience whose intensity was pleasurable and dreadful at the same time. Set in threatening natural landscapes from the temporal past, Gothic narratives featured solitary castles harbouring horrific secrets, where innocent females were imprisoned at the mercy of evil, powerfully erotic men. As the notion of "Gothic" widened into an object of multi-disciplinary scholarly enquiry, it expanded on its original iconography of ruins and graveyards, while retaining core features such as disorienting environments, sexual anxiety and obscure powers. Vast and 
developing as the field now is, ranging from geography to new media studies, it is possible to identify some key forms and meanings as a working model for Gothic analysis. At the centre of this model, lording over uncanny natural landscapes and claustrophobic interiors, stands the Gothic male villain. A satanic character inducing both terror and attraction in his usually female victims, the Gothic male triggers a special kind of sexual fear: repulsive yet irresistible, he poses a menacing lure which cannot be escaped. This mixture of seduction and horror marks him as a figure of abjection. Conceptualizations of the Gothic abject are largely inspired by the work of Julia Kristeva (1982), and focus on two key properties of abjection: its ambiguous power of attraction-repulsion, and the impossibility of its full removal. Approached by Kristeva as unwanted matter that the subject casts aside, yet cannot entirely destroy or get rid of, the abject invests the Gothic male with an irrational quality, a fascinationproducing grossness. If Frankenstein's monster is an abject Gothic figure, as Kelly Hurley suggests (2007: 137-139), so is, according to Brian Baker, The Silence of the Lambs's Hannibal Lecter (2007: 168-169). Sexual anxiety is mostly felt by and on behalf of female victims: faced with the dangerous unknownoriginally symbolized by walls or dark forests, and personified by the satanic male typically intent on rape and/or incest-women in the Gothic nightmare are prey to a distinctly masculine force that both terrifies and compels. As Kristeva puts it, "like an inescapable boomerang, a vortex of summons and repulsions" (1982: 1), the power of abjection is almost impossible to defy: its presence inside one's consciousness cannot seemingly be evicted. And indeed, the satanic Gothic male haunts the psyche even when he is physically absent. Nor can death dispose of him: he remains narratively crucial, functioning as a structuring lack over the remaining characters (who contrast him by their extreme insipidness) and plot (very little happens once the male villain has died). Just as his power over women remains unexplained, the indefinable longing following his death cannot be rationally accounted for.

Blind Husbands and Foolish Wives revolve around an abject male presence. More embryonic in Blind Husbands, fully articulated in Foolish Wives, the male villain's abjection is expressed in the films through three, overlapping channels. One is the villain's appearance; another is the range of motives and actions associated with him; and the third is the conflictive and terrible appeal he has for his victims. To these visual, performative, and narrative elements, a final one must be added, which is the films' unsatisfactory ending: Von Steuben and Karamzin are dead, yet the American wives' re-commitment to their marriages is far from convincing, troubled by the gap between their husbands' infinite dullness and Stroheim's wicked attraction.

Erich von Stroheim's appearance dominates these films. Although he favoured immaculate, tailored suits when he was off-screen, in Blind Husbands and Foolish Wives Stroheim constructs his own sartorial nightmare. Wearing a fussy, tightfitting military uniform most of the time, he never looks like a soldier; despite his frequent heel-clicking and martial salutes, his looks recall the army only in the most distorted way. Both swamped and corseted by his elaborate costumes, which literally squeeze out of him a faintly anomalous quality, Stroheim appears as a petite, disquieting creature halfway between snake and weasel; bedecked with military insignia, he highlights yet perverts the signs of virility. Rather than the Evil Hun's hyper-masculinity, he presents an uncanny aberration of manhood, and he would certainly not fit in the Austrian army patrol of Blind Husbands. The uncanny is a prime attribute of the Gothic; related above all to a blurring between the known and the unknown, the familiar and the unfamiliar, it is defined by Nicholas Royle as "a crisis of the proper" and "of the natural" (2003: 1). Un-proper and unnatural, Stroheim's appearance is a coded expression of the disturbing meanings linked to his roles. Over-equipped with the props of military might, and strutting around in their glory much as a dominatrix would carry a whip, Stroheim also evokes the contemporary trope of the "lounge lizard", a grooming-obsessed foreign man devoted to fashion and womanizing. But while Rudolph Valentino, a handsome tango champion, typified the lounge lizard's sexy looks, Stroheim's rat-like appearance utterly deforms the type. The result is an alien perversion of the known, a degeneration of masculinity which, simultaneously, aligns itself with male orthodoxy: revelling in virile items such as uniforms or guns, and motivated by an often lethal heterosexual drive, the abnormally coded Von Steuben and Karamzin exhibit the abjection of sexual Otherness. Imbuing with a strange repulsiveness the stock figures of officer and aristocrat, yet exuding a powerful fascination through its compelling and menacing difference, Stroheim's appearance performs the emotional aesthetics of the Gothic. At the same time, the eroticism attached to his deviant looks stresses his Gothic agency, his sexual power of seduction and abuse; this is greatly facilitated by the films' plots, which not merely eroticize him but turn him into the only sexualized man on screen. The abject dualism of Stroheim's repulsion-attraction, and its devastating power, are clearly shown from the beginning of the films. In Blind Husbands, the smiling Von Steuben first seen in the carriage soon gives way to a more complex figure: when the village men look at him with curiosity, he returns their gaze with a glacial stare, imparting curt orders and ascending the hotel staircase which the crowd, instinctively making way for him, has freed for his passage by parting in two. He finds time to rapidly size up a pretty girl, changing his icy expression to an interested smirk, and receiving her flirtatious smile. It is the next day's breakfast scene, however, which sets the tone for Von Steuben's dualistic mode of seducer and persecutor. Having retrieved Margaret's sweater, he sits at a table opposite hers; after studying her briefly through his monocle, he rubs his hands in anticipation. While he is given the menu by a solicitous, clearly smitten waitress, Von Steuben now trebles the level of his behaviour: through an extraordinary facial performance defined by quick and eloquent shifts, he establishes friendly eye contact with Margaret, transforms it into a ruthless controlling gaze when she looks away, and all the time flirts with the waitress. Margaret seems troubled and intrigued by his stare; Stroheim keeps their connection going through his eyes, but changes their expression from inviting to coldly predatory. In the space of a few seconds, his moving countenance has signalled keen interest to her, and chilling scheming to the audience. He then lifts his head towards the waitress, breaking into a leery smile, only to return his attention to Margaret with a piercing look; his lower face stiffens as he purses his lips, moving his chin forward in steely determination. When Margaret gets up from the table, leaving her husband absorbed in a book, Stroheim shifts his body onwards, as if ready to spring into action: his eyes are glued to his prey, and he now smiles to himself with a triumphant expression. All this is accomplished with the waitress intimately close behind him, obediently awaiting her turn; he finally talks to her, kisses her on the mouth, and prepares to follow Margaret outside. This sequence establishes Von Steuben's power over the female, be she a random local girl or a married American lady; at the same time, his menacing, pitiless appraisal of Margaret, and the chase that follows it, confirm him as a threatening presence.

Foolish Wives also introduces Karamzin's unsettling traits through a breakfast scene. First sighted while shooting by the seashore, the Count soon joins the ladies for the morning meal; seated between his glamorous "cousins" who vie for his attention, he is also attended by Maruschka, who goes as far as placing a 
cushion under his feet. Looking irascible and domineering, accepting their lavish care as a given, Karamzin proceeds to drink a full glass of oxblood: this action is shown in a lingering close-up, allowing for a full view of his features relaxing at the taste of blood. After this obvious reference to vampirism, the film moves on to Karamzin's meeting with Marietta, setting up an especially distressing aspect of his character and motivation. The counterfeiter's daughter is not just an innocent girl; she is also mentally confused and, despite her shapely womanly body, firmly anchored to childhood. Her obsessive hold of a doll, and her needy proximity to her father, are clear indications of her mental and emotional age. By repeatedly crossing herself in the Villa, as if in a church, she suggests spatial displacement; her frightened manner and dilated eyes, however, point to the evocation of protection in the face of menace. When Olga attempts to give her a friendly caress, she recoils in alarm. Fear, however, leaves Marietta's eyes when she remains alone with Karamzin, giving way to utter fascination. Stroheim slowly circles around her in a vulture-like movement, finally standing still by her side, smoking; his gaze moves from her face to her body, then behind him to check no-one's there, then again to her face and breasts. There is a hint of a smile on his lips, which he licks with his tongue, and he motions upwards with his eyes and head, clearly inviting the girl to follow him upstairs. Marietta nods, enthralled by his every expression; visibly more relaxed, she shows him her doll. At this point Stroheim turns his back to her, and starts applying perfume to his neck and mouth, even swallowing the fragrance as he gargles with it: an excessively elaborate prelude to an erotic encounter. Marietta, now entirely at ease, moves nearer to him to better see what he is doing: Stroheim looks at her amusedly, even tenderly, and repeatedly touches her nose with the perfume bottle to let her inhale the scent. Still smoking, still holding her in his gaze, he gives her the bottle to keep. Marietta starts putting the perfume on her doll. The film cuts to Olga and Ventucci checking the banknotes, then returns to Stroheim, who is now holding and caressing Marietta's arm; he quickly lets go as the others come back. The whole scene has a disturbing intensity, as the anxiety generated by the girl's situation is mixed to the erotic charge brought by Stroheim's interaction with her. As James R. Kincaid has argued, paedophilic narratives are intimately linked to the Gothic. Relying on a "melodrama of monsters and innocents" (1992: 27), popular representations of child-molesting adopt Gothic tropes. Even more darkly, it may be added that the often murky relationship between children and their abusers, the troubling emotive closeness between them, echoes the repulsionattraction at the basis of Gothic abjection. In Foolish Wives, Karamzin plays the lover with Marietta exactly as he does with his other preys; and just like them, Marietta responds with thrilled attraction, tempered this time not by scruples and fear, but by her lack of awareness. Posing this girl-child as someone who partly allows Karamzin to determine her fate, and Karamzin himself as the only character, aside from her father, that Marietta likes and trust, Foolish Wives makes his monstrous protagonist an object of his victim's desire. It may not be definite sexual desire, but it certainly involves the senses, as the role of the perfume shows.

A confusedly rather than conflictingly willing victim, Marietta does not establish a periodic relationship with Karamzin, and, therefore, figures much less in Foolish Wives than Mrs Hughes, or than Margaret in Blind Husbands. Equally, as the film provides no visual record of her last meeting with the Count, there is no indication as to whether she experienced fear and terror like the other women preys. Nonetheless, some aspects of her interaction with Karamzin make her a symbolic character, helping to articulate the Gothic power of Stroheim's satanic male. With irrationality inscribed in her appearance, and confirmed at various times by Ventucci, Marietta emphasizes the incomprehensibility of Karamzin's allure, reinforcing the mystery of its laws. But it is in their final meeting that Marietta becomes a sign linking together Stroheim's victims, thus visually codifying his menace. This happens through the modalities of Marietta's spatial and temporal position: in bed, at sleep time. A major Gothic trope, the sleeping woman besieged by an evil seducer is not just an aesthetic convention: it also recalls the sublime, whose interwoven notions of pleasure and horror are reunited in the image of the bed. As a place connected to sleep and sex, dreams and nightmares, and thus to extreme vulnerability, the bed-locus speaks of the irresistible self-surrender to abjection. Nesting in the shade of menace is a metaphor invoked at the beginning of Blind Husbands, when Cortina is described as "chocked" by the surrounding Alps; it is also explicitly used in that most canonical of Gothic works, The Mysteries of Udolpho. As a definition of "a perfect picture of the lovely and the sublime", the novel proposes "beauty sleeping in the lap of horror"(Radcliffe, 1998: 55). In Blind Husbands and Foolish Wives, the beauties Margaret, Mrs Hughes and Marietta are literally and symbolically "in the lap of horror", and bed scenes are pivotal to their relationship with Stroheim's characters. While a physical lap can be read in Stroheim's sexually predatory behaviour and motivation, a symbolic lap is constructed by his mastery of the emotional, erotic and mental world inhabited by his preys.

Two bedroom scenes in the films particularly stress Stroheim's abjection, while situating him in a visual and performative frame saturated with Gothicness: the first takes place in Margaret's hotel room, the second in Mother Garoupe's home. In the first case, Von Steuben's interaction with Margaret strongly recalls Dracula narratives, while the latter scene bears remarkable similarities to The Nightmare (1781), Henry Fuseli's famous painting, thus bringing classic Gothic imagery to life.

As soon as Von Steuben enters Margaret's bedroom, he is framed with her in a mid-shot by the closed door, listening for the steps of a suspicious maid outside. His dark military uniform contrasts with Margaret's extreme whiteness, as she is wearing a pale sleeveless nightgown, which exposes her almost translucent skin. Her naked shoulder is very close to Von Steuben, whose gaze shifts to it, and who imperceptibly bends down towards it, almost breathing it in and savouring it. Stroheim achieves this vampiresque effect by a rapidly shifting, yet intense expression of voluptuousness in his darting eyes, while his nose and mouth are pointed towards Margaret's flesh. When she next puts on a loose dressing gown, which fails to cover her scanty nightdress, Von Steuben gets hold of her hands, kissing them and keeping hold of them as she walks backwards into the room; proceeding in this fashion, they reach the four-poster bed, and stand in front of it. Von Steuben now embraces Margaret, whose resistance seems to dissolve as he glides over her body with complete ease; he smiles diabolically, and kisses her forcefully on the mouth. Margaret's eyes are dilated with panic, yet she does not recoil from his kiss. Against the white background of the bed's curtains and linen, the couple provide a picture of white-on-white beauty, terrified yet excited, ensnared by dark and inexorable masculinity. All the while, Von Steuben has been whispering to Margaret, who after pleading for time has begun to nod in response; when he finally lets her go, he appears to impart some orders, lifting his finger in admonishment, and again she nods submissively despite her agitation. Indeed, she is still nodding in agreement when they say goodbye, with Von Steuben already outside the door. The whole scene, featuring a white-gowned, long-haired woman in a state of alarmed trance, responding to a terrible male power in her bedroom, brings to mind a key moment in FW Murnau's Nosferatu (not to be released for another three years), when the sleeping wife is awakened by the unseen, yet all-pervading presence of the vampire. In Blind Husbands, the next bedroom 
scene has Margaret asleep while her husband watches her: she is wearing the same nightgown, and is again framed by the bed's white curtains and sheets. Her face is also exceedingly pale, as unbeknown to her consort she is dreaming of Von Steuben: her nightmare vision fills the screen, as the Lieutenant's demonical smirk is followed by a giant image of his hand, pointing with his finger. It is a clear summon, and Margaret wakes up in a fright, as "beauty asleep in the lap of horror" is wont to do.

In Foolish Wives, when Mrs Hughes is sleeping in the alien environment of Mother Garoupe's, she is entirely surrounded by Gothic menace. Stroheim's genius for mise-en-scene shines through the design of this bed-chamber, rendered even more unsettling by the stormy night, and by the creatures passing through it. As torrential rain pelts outside the small windows, which let in only a feeble illumination, the low ceiling and thick walls close in around the bed; the impression is of a place carved out of rock, as the walls are stooped and made of rough blocks of stone. There is no clear divide between the various parts of the dwelling, which resembles a cave-like catacomb. Unidentifiable rags hang randomly everywhere, and crumbling furniture restricts the floor space. A goat walks around freely, and is joined later by a large dog; no boundary separates animals from humans, and indeed the horned goat looks especially fond of Karamzin, following him closely. Garoupe, hobbling on primitive crutches, is dressed in tattered clothes, and her malicious smile reveals an almost toothless mouth. A strong sense of decay pervades the scene. In this setting Mrs Hughes is put to bed by the Count and his witch-like accomplice; they cover her with a thick duvet, whose bulky pattern uncannily resembles the stone walls. Later, the goat jumps on the bed, followed by the dog. An animalist presence remains strong throughout the sequence, even when Karamzin has to leave Mrs Hughes: at this point an owl and two large frogs come into view, apparently staring at the Count. It is notable that while animals and humans share their space, this proximity conveys none of the cosy undertones of pet ownership, or the cuteness of farm animals: it rather strengthens the unnatural quality of the place, amplifying its associations with degradation and foulness. In other words, Garoupe's home is a site of abjection: it suggests eerie menace and waste matter, as much as the sexual anxiety caused by Karamzin. The latter does not give up his schemes easily. After the monk's arrival has interrupted him, he returns to his position on Mrs Hughes's bed, and while she continues to sleep he caresses her arm; aware of the monk's scrutinizing gaze, he remains seated, partially obstructing and thus dominating the sight of his prey. Still next to her, he finally crosses his arms, as a cunning smile plays fleetingly on his face. Stroheim's peculiar appearance, his menacing attitude, and his hovering over a pretty woman asleep, in a distinctly sinister place, altogether offers an apt rendition of "beauty sleeping in the lap of horror" (Fig. 4). The scene is also a visual reminder of Fuseli's The Nightmare, where a small, malevolent goblin sits on top of a sleeping woman, with a dark horse at his side. Last, Karamzin's ruinous allure for the helpless Mrs Hughes recalls the strange power that Von Steuben holds on Margaret. The same, almost otherworldly power is acknowledged all along in Foolish Wives, as on the very first meeting between Karamzin and Mrs Hughes, the camera shows what book she is reading: it is a volume entitled "Foolish Wives" and the author is "Erich von Stroheim" (Fig. 5). The American lady is literally following a preordained script: Stroheim's script. While Stroheim himself, blurring the divide between screen life and real life, is playing Karamzin and thus plotting her fate.

Power over the female is a prime attribute of traditional masculinity, but the quasi-supernatural, aberrant influence of Stroheim's protagonists imbues their manhood with Gothic ambiguity. Just as their contradictory repulsion-attraction speaks

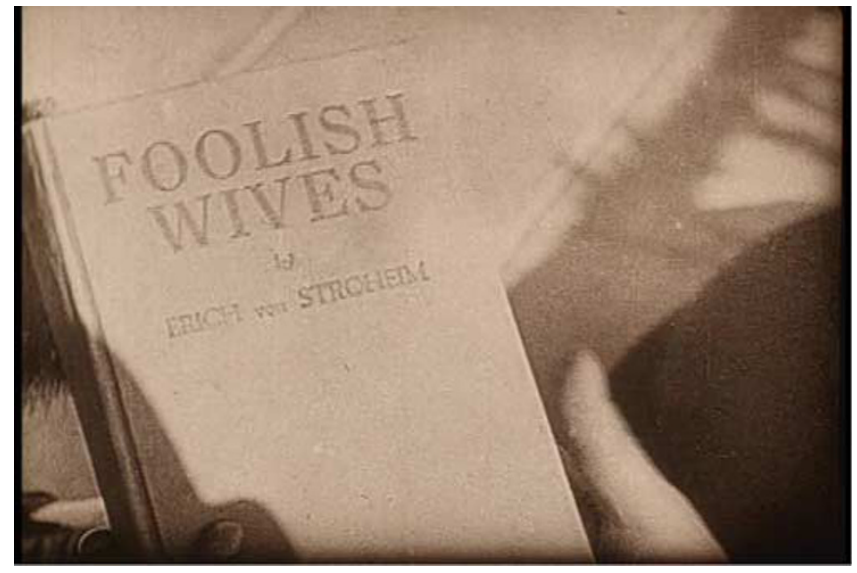

Figure 5 | Stroheim's script seals Mrs Hughes's fate. From Foolish Wives (Erich von Stroheim, 1922). This figure is not covered by the Creative Commons Attribution 4.0 International License. Reproduced with permission of the copyright holder, Kino Lorber, Inc.

of abjection, so their unnatural yet successful womanizing can be referenced to key Gothic figures. In a discussion of Dracula, for instance, Andrew Smith notes how the vampire's dominance and allure make him "an implied role model of manliness" for his male adversaries, yet "to become like him is to play the degenerate". This dichotomy, argues Smith, remains "a paradox never resolved" (2004: 37). Such a paradox is at the heart of Blind Husbands and Foolish Wives, embodied in the persons of Von Steuben and Karamzin. Supremely attractive to women, yet also repulsive and "degenerate", they posit a contradiction which is "never resolved", as their apparent defeat and literal destruction are not validated by the films, whose restoration of the American marriages rings hollow and unconvincing.

While ambiguity and abjection are chiefly located in Stroheim's male protagonists, these men's relation to their surroundings is equally defined by unsettling meanings. The "lap of horror" of the satanic male is not just bodily and emotional, but also spatial, as Von Steuben and Karamzin are connected to abominable topographies. It is only fitting that the latter's body ends up in a sewer, reunited with filth and waste: the Count may have been part of Montecarlo's elite, yet despite his immense seductiveness he was a vile individual (and a fake aristocrat). At the same time, the notion of "dreadful pleasure" which makes Ann Radcliffe link beauty with horror, resonates with the death of Von Steuben, which is a literal engagement with the sublime.

The "aesthetics of terror" of Gothic tradition are especially linked to mountain landscapes, a recurrent motif in early Gothic fiction. Comprising vertiginous heights and drops, wild scenery, and eerie isolation, mountainous worlds conform to, yet complicate Burke's notion of the sublime, itself a delicate balance between ecstasy and terror. As Robert Miles explains, "A sight of nature's vastness from the top of a mountain would be sublime; the same view from the perspective of someone falling down it would be simple terror"(2007: 14). The sublime, in other words, should not be directly confronted; yet Von Steuben does. In Blind Husbands, the two characters initially linked to the mountain, Sepp and Dr Armstrong, experience it with neither ecstasy nor terror: Sepp is simply at home there, while the American shows no emotion when rescued by the former, or when he reaches the Pinnacle. Von Steuben, on the other hand, is first associated with the Alps in a reference to horror, through his obvious narrative link to the seducer from the past, pushed off the mountain to his death by a jealous husband. Later, he alone in the film experiences the mountain on a deeply emotional level, as his reaction to being 
on the Pinnacle is one of hysteria and utter dread. Closer to the sublime than anyone else, Von Steuben is killed by the mountain as he falls off the Pinnacle, prey to a total loss of control; however, the long shot documenting his fall does not show him clearly or even recognizably, so that the "simple terror" which ought to replace the sublime is absent, leaving intact the powerful effect which the Pinnacle, or rather the view from it, had on his psyche. Von Steuben's death takes the sublime to a logical conclusion, by overstepping the barrier between observation and direct contact with its dreadfulness.

Perhaps the most complete expression of Gothic spatiality occurs in Foolish Wives. An attribute of the Gothic is the unsettling collapse of centre and margins, already manifest in the duality of the Gothic villain; as Emma McEvoy points out, he can function within and without the system, although he is ultimately "beyond the pale"(2007: 24). This is exactly Karamzin's position in the social narrative of the film. However, this ambiguity also applies to the space that Karamzin traverses and conjures: when he takes Mrs Hughes for a walk, his trajectory brings about a shift from urban, sophisticated, familiar Monte Carlo to an alien environment, which is markedly "Calibanish" (Lennig, 2000: 152). In the process, the forces of nature turn the normal into the apocalyptic, and the storm elides any reference to the city known to Mrs Hughes. Far from being unsettled, Karamzin is master of these new coordinates; managing storm, flood and isolation from the outside world, he brings his prey to unspeakable lodgings, not remotely associated with the place and time they have just left. Aligned with the Uncanny, the Count alone revels in its dimension, in how "its "un" unsettles time and space, order and sense" (Royle, 2003: 2). Last, the dreadful finale to the relationship between Karamzin and Mrs Hughes combines madness, fire and death. In a passing nod to Jane Eyre, the unhappy Marushcka is driven to insanity from jealousy and neglect, and turns to arson and suicide. What had started as a routine soiree for the Monte Carlo elite, and as a thrilling meeting between the Count and Mrs Hughes, becomes a hellish scene of flames and fatal danger.

During the shooting of Foolish Wives, Erich von Stroheim was interviewed for the Motion Picture Magazine, and the resulting article was entitled "Satan on a Leash". The phrase was repeated in the text, as a comment on the fact that Stroheim ("Satan") was always accompanied by his wife on set, allegedly to disprove his womanizing reputation. Thus literally defining the real-life Stroheim as satanic, the article also blurred reality and fiction, shifting from its subject's supposed philandering to his on-screen seductions. To the question "Why is it [...] that almost all women are attracted to the type of men you portray on the screen?", Stroheim was said to reply "It is because all women, whether they be peasant or princess, Judy O'Grady, or the Colonel's lady, all love the twinkle of the devil in a man. In the parts I play, I am that, and a little more" (Gassaway, 1921: 84). The outrage which was to greet the release of Foolish Wives points to an unmitigated, unapologetic exposure of that "little more", and to the validation of a "Satan" who is no longer on a leash. Confirming the reporter's belief that Stroheim's characters were irresistible to "almost all women", Foolish Wives joined and surpassed Blind Husbands in having a demonically alluring male protagonist, to whom no female is immune. In this blurring of horror and erotic power lies the films' main transgression: not in the mockery of Americans, not in the affirmation of disliked national stereotypes, but in the celebration of Stroheim's abject, unspeakable, unthinkable Gothic males.

\section{References}

Baker B (2007) Gothic masculinities. In: Spooner C and McEvoy E (eds). The Routledge Companion to Gothic. Routledge: London, pp 168-169.

Fischer L (1994) Enemies, a love story: Von Stroheim, women, and World War I. Film History; 6 (4): 552-534.

Gassaway G (1921) Satan on a Leash. Motion Picture Magazine; XXII (9): $40-41,84$.

Kincaid JR (1992) Child-Loving: The Erotic Child and Victorian Culture. Routledge: New York, NY.

Kristeva J (1982) Powers of Horror: An Essay on Abjection. Columbia University Press: New York, NY.

Hurley K (2007) Abject and Grotesque. In: Spooner C and McEvoy E (eds). The Routledge Companion to Gothic. Routledge: London, pp 138-139.

Lennig A (2000) Stroheim. University Press of Kentucky: Lexington.

McEvoy E (2007) Gothic and the romantics. In: Spooner C and McEvoy E (eds). The Routledge Companion to Gothic. Routledge: London, pp 19-28.

Miles R (2007) Eighteenth-century gothic. In: Spooner C and McEvoy E (eds). The Routledge Companion to Gothic. Routledge: London, pp 10-18.

Radcliffe A (1998) (first published 1794) The Mysteries of Udolpho. Oxford University Press: Oxford.

Royle N (2003) The Uncanny. Manchester University Press: Manchester.

Smith A (2004) Victorian Demons: Medicine, Masculinity and the Gothic Fin-deSiecle. Manchester University Press: Manchester.

Staiger J (1992) "The Handmaiden of villainy": Foolish wives, politics, gender orientation, and the other". In: Interpreting Films: Studies in the Historical Reception of American Cinema. Princeton University Press: Princeton, NJ, pp 124-138.

\section{Data availability}

Data sharing is not applicable to this article as no datasets were generated or analysed during the current study.

\section{Additional information}

Competing interests: The author declares that there are no competing financial interests.

Reprints and permission information is available at http://www.palgrave-journals.com/ pal/authors/rights_and_permissions.html

How to cite this article: Girelli E (2017) "Beauty in the lap of horror": the Gothic appeal of Erich von Stroheim in Blind Husbands (1919) and Foolish Wives (1922). Palgrave Communications. 3:17082 doi: 10.1057/palcomms.2017.82.

Publisher's note: Springer Nature remains neutral with regard to jurisdictional claims in published maps and institutional affiliations.

\footnotetext{
(i) This work is licensed under a Creative Commons Attribution 4.0 International License. The images or other third party material in this article are included in the article's Creative Commons license, unless indicated otherwise in the credit line; if the material is not included under the Creative Commons license, users will need to obtain permission from the license holder to reproduce the material. To view a copy of this license, visit http://creativecommons.org/licenses/by/4.0/
}

(C) The Author(s) 2017 